\title{
Malay Epic and Historiography Literature Students' Perception Towards Interface Design Elements
}

\author{
Salmah J. N. Muhammad ${ }^{1} \&$ Khairul Z. Jasni ${ }^{1}$ \\ ${ }^{1}$ Faculty of Modern Languages and Communication, Universiti Putra Malaysia, Selangor, Malaysia \\ Correspondence: Salmah J. N. Muhammad, Department of Malay Language, Faculty of Modern Languages and \\ Communication, Universiti Putra Malaysia, 43400 UPM Serdang, Selangor, Malaysia. Tel: 603-8946-8676. \\ E-mail: salmahjan@upm.edu.my
}

\author{
Received: August 6, $2018 \quad$ Accepted: September 13, $2018 \quad$ Online Published: September 28, 2018 \\ doi:10.5539/ass.v14n10p31 URL: https://doi.org/10.5539/ass.v14n10p31
}

\begin{abstract}
The interface is an important element in delivering information. This is because the interface becomes an early attraction to the user's perception before going to the next level. A good interface design will emphasize easy and user-friendly elements. Unfriendly interface design may impact the activity provided. This study aims to identify, parse and analyze user ratings on interface design. The respondents of the study involved 87 BBK 3311 Malay Epic and Historiography Literature at Universiti Putra Malaysia. The emphasis of this study will focus on nine interface design elements. The quantitative approach is used to carry out this study. A questionnaire instrument specifically designed to assess respondents' assessment of the interface design. This survey is available online using the Survey Monkey website and analyzed based on the Technology Acceptance Model (TAM) approach. This is because this approach is specifically designed to analyze the acceptance of the technology. The results of the study showed the level of tendency of students to be interested in the interface design. The results of the study can also help in giving an overview to the online course builder on the interface design that affects students' interest. Furthermore, it is hoped that the results of this study will be a guideline in building interface designs in the website.
\end{abstract}

Keywords: design, interface, technology, TAM, Malay artistry

\section{Introduction}

\subsection{Introduction to Problem}

Interface design is an important part of receiving and transmitting information process between humans and computer systems. An interface is also a sub field of computer science. Building a design is important to facilitate the smooth learning process, making it easier for information to be communicated. Constructing a design should be carefully planned as well as meeting the requirements and standards of the user; this is because the design that is used as an interaction relationship connects the user with the system application. The development of a clear and easy-to-navigate interface does not make it difficult for users to interact and carry out the activities provided in the system. The interface also focuses on the visual display presented in a site whether printed or electronic that intermediates between visual displays with the user. Interface designs also need to be developed to make it appealing and to be effective in order to influence the way they interact. A clear interface includes graphics, texts and information presented to the public. Definition of interface provided by Galitz (1997, p. 13) states that the user interface is a combination of the techniques and mechanisms used to communicate with something. Additionally, he notes that the interface allows users to listen, look and touch as well as understand directly or indirectly. The interface is categorised into two that is output and input. Input includes material such as mouse, keyboard, screen and voice while the output touches on computer process and needs to the user. Jian Zhang et al. (2017) divided the interface into traditional and open. Traditional refers to the interface used to link specific modules in the interface design process. Meanwhile, an open interface is an interface used to connect platforms with unrecognized modules provided by manufacturers from third parties. Syahrul Nizam Junaini (2014) stated that the usability issues of the website are seen in some aspects including user-friendly. Rating of websites is assessed in terms of icons, menus and other interface elements that facilitate the user's understanding and interaction. This is important because the user's first experience is important to encourage revisit the same page or vice versa. The above studies are in line with studies by Azizah Jaafar et al. (2013) and Razli Ahmad, 
Hanum Hassan \& Azuddin Bahari (2013).

\subsection{Relevant Scholarship}

Hazwani Nordin dan Dhalbir Sigh (2016) touch on the e-learning that was implemented in the Malaysian education system. The application of e-learning can improve the quality of teaching and learning by encouraging the involvement and commitment of students in learning. The result of this study is the issues related to the interface design that are constantly changing according to the user's suitability. The success of the interface design helps students understand the meaning of the e-learning interface used. Yusup hashim (2012) also discusses the effectiveness of e-learning in teaching and learning. The exciting digital era focuses on e-learning that has shifted from technology to the era of learning design technology. The technology seen can play an important role in attracting students to explore the areas of interest. Therefore, the interface design is part of a contributor to encourage the student's interest in accessing a site over and over again. Meanwhile, Hazwani Mohd Najib, Noor Raudhiah Abu Bakar and Norziah Othman (2017) state that effective e-learning can produce highly self-taught students producing more literate students in technology indirectly and at the same time forming a holistic student in everything. The above studies are in line with a study by Ahmad Syukkri Adnan, Mumammad Ali Reza Ahmad \& Azfi Zaidi Mohammad Sofi (2015) on the utilisation of visual elements on interface design of e-learning.

The next study by Tengku Siti Meriam Tengku Wook et al., (2016) also touches on the face display. She noted that the technology approach is not immersive by implementing information visualization techniques and virtual reality as a visual interface display used as a model for developing communication designs among users in virtual museums. The following study by Tan Li Yin, Nazlena Mohamad Ali dan Shahrul Azman Mohd Noah (2016) in the assessment of the nutritional information interface design for the elderly states that nutrient-related information is now available easily through the internet. However, there are problems faced by the elderly because of their inability to adapt to the interface design. This is different from adult users. This study was carried out to take into account the results of the assessment from the focus group of the study. The above studies are in line with studies by Hashiroh Hussain \& Norshuhada Shiratuddin (2016) and Norasikin Fabil \& Zawawi Ismail (2018).

The following study looks at the promotion through the website by Hejrahtul Amani Halim and Zakirah Othman (2017) in covering promotional strategies conducted through a website consisting of two features which are aspects of the quality and aspect of the relationship to social sites. They listed that the quality of the site's content contains several aspects such as interface and design, data collection, navigation, search, pictures and unique language. Based on this study, the researcher concluded that interface display plays an important role in the promotion of a product. The uniqueness and capabilities of the interface help to promote more effectively. A proposed study is about speed, security and links to run in the future. Meanwhile, according to Rasyiqah Rusdi, Noraidah Sahari @ Ashaari and Siti Fadzilah Mat Noor (2017), the ideal interface for senior citizens should be more user-friendly in the aspect of color, language, large font, easy-to-use navigation and media integration such as video and audio-visual. Guidelines created must be in line with the target group.

Based on the above literature review, this study will identify and discuss the evaluation of interface design among BBK 3311 Malay Epic and Historiography Literature students. Additionally, this study will analyze and describe the items contained in the interface design based on the questionnaires that have been conducted.

\section{Method}

\subsection{Sampling Procedures}

This study will use quantitative methods to see the assessment of the interface design. This study was conducted at Universiti Putra Malaysia involving 84 respondents. The respondents of the study are students from BBK 3311 Malay Epic and Historiography Literature course. The location of the study was chosen because Universiti Putra Malaysia is an institution that offered the Malay Epic and Historiography Literature courses. Respondents also consist of students who study the course. This will make it easier for students to answer the questionnaire provided. The questionnaire instrument will be used in conducting this study. Questionnaire forms are available online by using SurveyMonkey's website. Question submitted consists of 9 items related to assessment of interface design. Respondents only need to answer SurveyMonkey online surveys. This instrument is used to save costs because researchers do not have to spend on printing costs. This study will also use the Technology Acceptance Model (TAM) theory. This theory was introduced by Davis (1986). TAM is a model developed for the purpose of analyzing and understanding the factors that influence the acceptance of information technology used. The TAM model developed from psychological theory explains the behavior of computer users based on the beliefs, attitudes, desires and user's relationship behavior. The purpose of this model is to explain the key 
factors of user behavior towards technology acceptance. More detail describes TI acceptance with a certain dimension that can affect TI by users. This model places the attitude factor of each user's behavior with two variables which are convenience and usefulness. These two variables explain the aspects of user behavior. The conclusion is that the TAM model can explain that user perceptions will determine their attitude in the benefit of TI users. This model illustrates more clearly that the acceptance of TI use is influenced by the usefulness and ease of use. This study uses 5 modules that have been modified from previous TAM research models which are perceptions of ease of use, perceptions of benefits, usage attitudes, behavior to use, and the apparent state of the system. The question in the questionnaire item is presented in the interface aspect in a display. Questions submitted are using interval scale of 1-5 $(1=$ Strongly Agree, $2=$ Agree, $3=$ Medium, $4=$ Disagree and $5=$ Strongly Disagree) which is to evaluate the level of respondent's consent to interface design provided.

\section{Results}

\subsection{Statistics and Data Analysis}

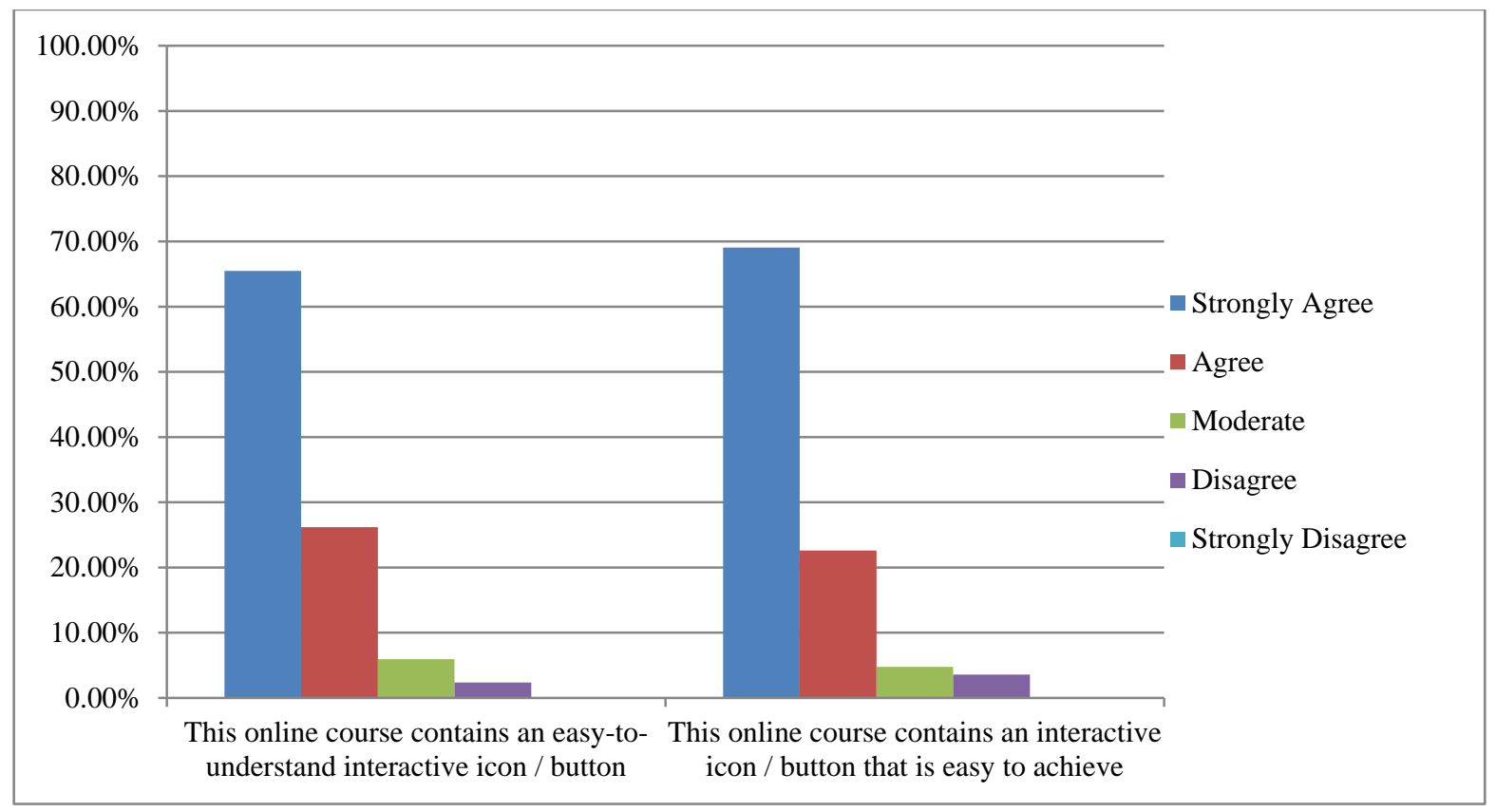

Figure 1. Assessment of the Interface Design for Item 1 and Item 2

Figure 1 above shows the Assessment of Design Interface for item 1 and item 2. Item 1, "This online course contains an easy-to-understand interactive icon / button" shows that 55 students (65.48\%) prefer to strongly agree while 22 students (26.19\%) choose to agree. Furthermore, none of the students chose to strongly disagree but 2 students $(2.38 \%)$ chose to disagree with the item. Meanwhile, 5 students $(5.95 \%)$ chose moderate. The above results indicate that students are more likely to use interactive buttons. It is also possible that the icon / button is easy to understand. Easy-to-understand icons help students to do activities quickly and easily because it does not take long to understand the meaning of each icon / button displayed. Item 2 in Figure 1 is "This online course contains an interactive icon / button that is easy to achieve". This item shows that 87 students (69.05\%) strongly agree and 19 students $(22.62 \%)$ agree. Furthermore, no one strongly disagrees and three $(3.57 \%)$ students disagree with item 2. Four students (4.76\%) chose moderate. The result of item 2 indicates that it is easy for students to achieve the interactive button provided. This is because most students are more proficient in technology and make it easier for them to know the icons / buttons provided without having to look for icons / buttons to access.

Based on the usefulness of the concepts in the theory of technology acceptance model, the result of data processing, the value of strongly agree for both items is among the highest compared to others. This is because, respondents have the perception that these two items provide information that there is a significant influence on the attitude of the user because it fulfills the requirements in the interface of a website that is easy to understand and easy to achieve. These two items are the main requirements for building a website because it can drive users to the next level up to real users. Therefore it can be concluded that in item 1 and item 2 analysis benefited respondents who are real users. 


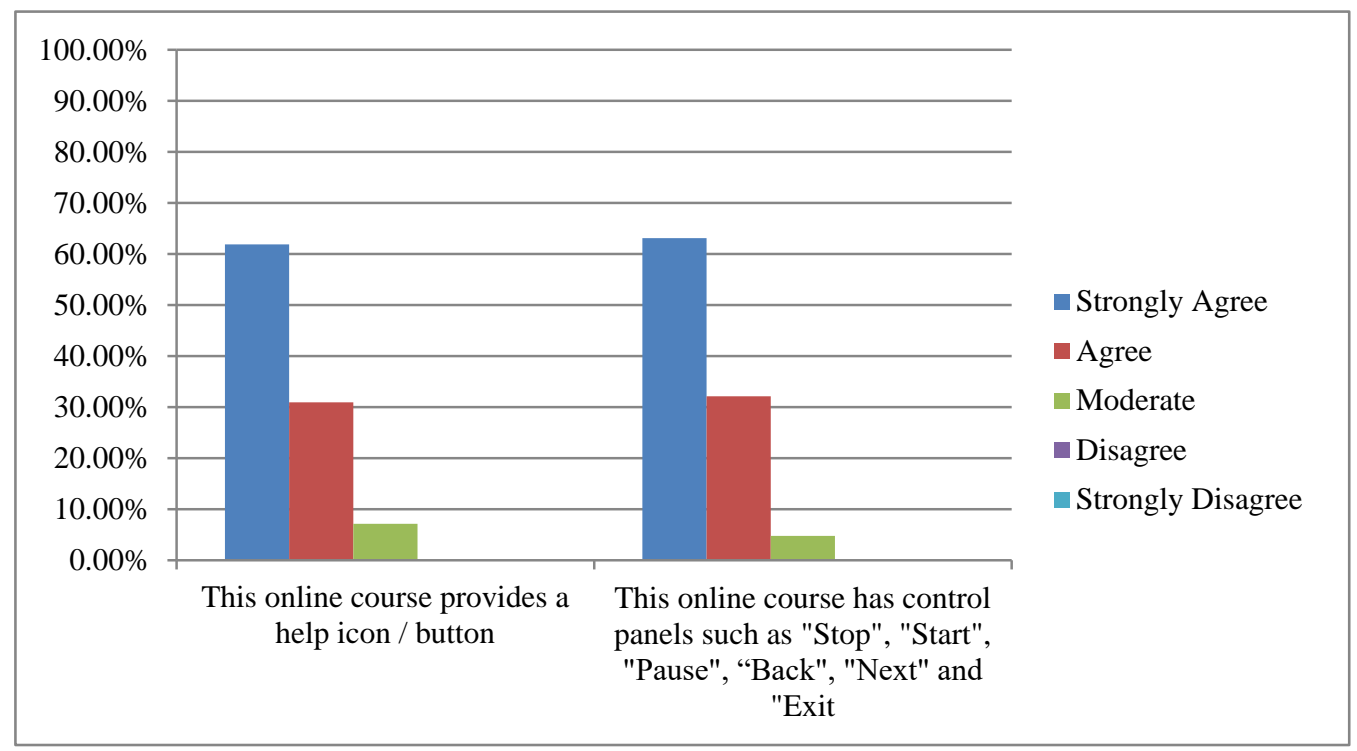

Figure 2. Assessment of the Interface Design for Item 3 dan Item 4

Figure 2 above shows the Assessment of the Interface Design of item 3 and item 4. Item 3, "This online course provides a help icon / button" shows the highest number to strongly agree with 52 students (61.95\%) followed by 26 students (30.95\%) agree. Next, no student chose strongly disagree and disagree with item 3. Meanwhile, 6 people $(7.14 \%)$ chose moderate. Results show that the majority of students agree this item provides a help icon / button. This is because the help icon / button is clear and accessible to students. Students can use the help icon / button provided. Item 4 in Figure 4 "This online course has control panels such as "Stop", "Start", "Pause", "Back", "Next" and "Exit" showed the highest percentage (63.10\%) as many as 53 students chose to strongly agree and followed by 27 people $(32.14 \%)$ chose to agree. While no student chose to strongly disagree and disagree with this item. Next, up to 4 people (4.76\%) chose moderate with item 4 . The results show students are more likely to choose to strongly agree with this item. This is because, this item is very important to help students carry out the activities provided in this course. The control panel provided may be clearly achieved by the student.

Furthermore, based on the Technology Acceptance Model, Perceived Ease of Use-PEOU, the analysis of items 2 and 3 show these items are accepted as most respondents strongly agree that the items are available in the questionnaire provided. This can drive their desire to behave as an actual user of the website. Users will be encouraged to use websites that are easy to access if it is clear and user-friendly.

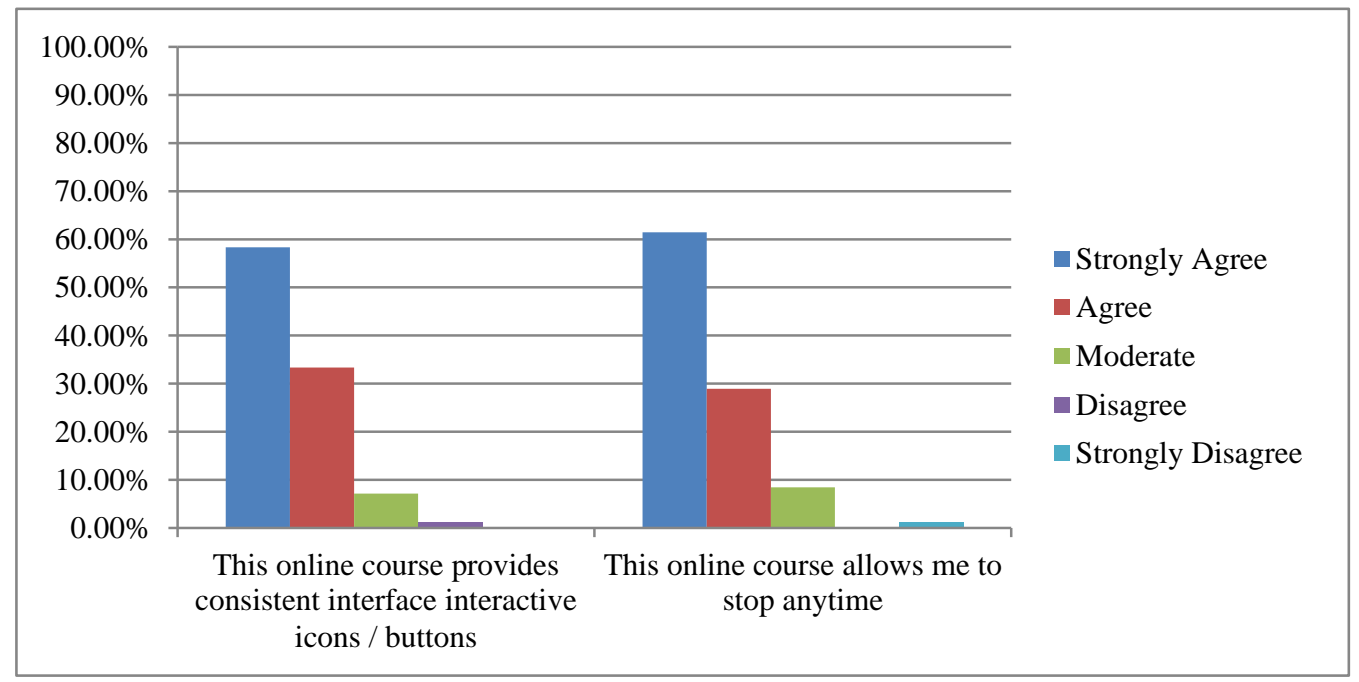

Figure 3. Assessment of the Interface Design for Item 5 dan Item 6

Figure 3 shows the Assessment of the Interface Design of item 5 and item 6. Item 5, "This online course provides consistent interface interactive icons / buttons" showing 49 students (58.33\%) strongly agree with this item 
followed by 28 students (33.33\%) agree. Meanwhile, no student strongly disagrees and (1.19\%) 1 person disagrees with the item. Next, 6 students claim that it is possible that consistent interface icons / buttons help students understand the content provided. 1 student $(7.14 \%)$ chose moderate. This item shows the most strongly agree results. Hence, students can make the activities more consistent and know the position of the icons / buttons more easily.

Next, item 6 is "This online course allows me to stop anytime" indicating that 52 students $(61.45 \%)$ choose to strongly agree and 24 students $(28.92 \%)$ agree. Next, 1 student $(1.20 \%)$ strongly disagrees with the item and no one disagrees. Meanwhile, 7 students $(8.43 \%)$ choose moderate. Overall results show that students tend to choose strongly agrees compared to the others. This is likely because, students can stop and resume activities that are created at any time. This online course requires students to have the internet to access and facilitate students to perform activities easily and according to student time.

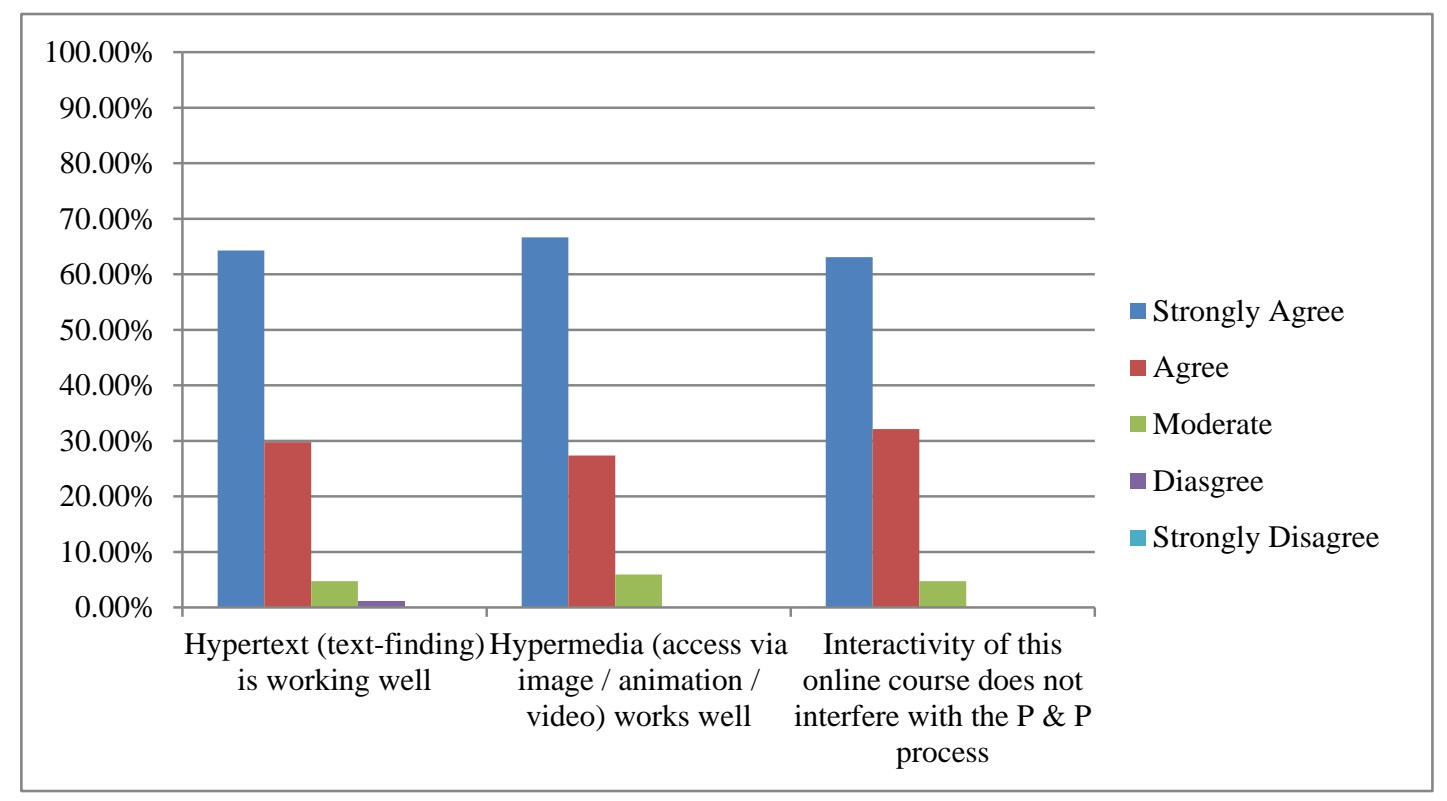

Figure 4. Assessment of the Interface Design for Item 7, Item 8 dan Item 9

Figure 4 shows the Assessment of the Interface Designs for item 7, item 8 and item 9. Item 7, "Hypertext (text-finding) is working well" shows that 54 students $(64.29 \%)$ chose to strongly agree and 25 students $(29.76 \%)$ to agree. While no students chose to strongly disagree and 1 student (1.19\%) disagrees with this item. Next, only 4 students $(4.76 \%)$ chose moderate. The results are more likely to be strongly agree as the texts being delivered is working well and help students to understand each activity provided. Access via good texts helps students to engage in activities easily and quickly.

Item 8 in Figure 4, "Hypermedia (access via image / animation / video) works well, indicating that 56 students $(66.67 \%)$ strongly agree and 23 students $(27.38 \%)$ to agree. While no student disagree and strongly disagree, but 5 students $(5.95 \%)$ chose moderate. Students are more likely to strongly agree with the above figure. This is likely because, students are more interested in images, animation and videos in the carried out activities. The media can help to attract the students' attention into doing activities and more interesting than texts. Hence, activities can be implemented well and easy to understand.

Next, item 9, "Interactivity of this online course does not interfere with the $\mathrm{P} \& \mathrm{P}$ process" shows that 53 students $(63.10 \%)$ strongly agree while 27 students $(32.14 \%)$ agree. No student disagree and strongly disagree with item 9 . Next, 4 students $(4.76 \%)$ chose moderate. The results show that students strongly agree that this online activity does not interfere with P \& P. This is likely because, the students are excited about the activities done online and it can help them in learning. Hence, online activities provide them with exposure and easy to understand subjects learned.

Based on the result of data processing, the value of strongly agree is higher as shown in Figure 4. The results of this analysis provide benefits to users in the technology acceptance model. The interface presented provides the perceptions of facilities that affect the usage attitudes influenced by consumerism attitude towards user behavioral interest. The results show that the use of websites can provide information system benefits. 
Respondents comprising university students can utilize the system to collect information for learning and lecture before starting a course in the classroom.

\section{Discussion}

In conclusion, the highest percentage of items that strongly agree is the second item that is 58 students $(69.05 \%)$. While item 5 shows the least to strongly agree with a total of 49 students $(58.33 \%)$. Furthermore, for the total numbers of students agree has the highest number of 28 students (33.33\%) for item 5 compared to item 2 which was the lowest with only 19 students $(22.62 \%)$. In addition, the results show item 6 has the most strongly disagree with 1 student (1.20\%). For ratio of disagree, the highest is item 2 which shows 3 students $(3.57 \%)$. At the same time, item 6 shows the highest achievement for a moderate with the amount of 7 students $(8.47 \%)$. Most of the lowest result shows 4 students (4.76\%) for item 2, item 4, item 7 and item 9. The results show that students are more likely to choose things that are easy and easy to achieve as shown in item 2. Additionally, students also tend to be interested in things that are consistent with the interface because something consistent will be easy to understand and navigate. Furthermore, the results also show that students love things that are animated and images. This is because nowadays students tend to be more interested in these things. Generally, the results of this study are very similar to the study conducted by Syahrunizam Junaidi (2014), Normaliza Abd Rahim, Awang Azman Awang Pawi \& Nik Rafidah Nik Muhamad Affendi (2018) and Normaliza Abd Rahim, Nik Rafidah Nik Muhammad Affendi \& Awang Azman Awang Pawi (2017) which state that there is a weak and less popular social media integration constraint and a slow display. Complex site design makes it difficult for users to access websites easily. Design improvements are also suggested to be more compact and user-friendly. This is because the user-friendly design will make the website a one-stop consumer choice.

This study focuses only on BBK 3311 Malay Epic and Historiography Literature course students at Universiti Putra Malaysia. This study is expected to benefit the Ministry of Education to develop programs on websites that emphasize the use of technology. The ministry can examine the importance of interface design before building any program for teaching and learning activities by using online technology. Furthermore, this study can also help online course builders to design an interface design to increase students' interest in pursuing online learning. It is hoped that future research will be more focused on the basic elements in the design of wider interface. Other studies such as display styles and layout of multimedia elements are widely carried out to ensure that each interface design built is beneficial to users and students.

\section{References}

Adnan, A. S., Ahmad, M. A. R., \& Sofi, A. Z. M. (2015, June 8-9). The Utilisation of Visual Elements on Interface Design of e-learning. International Conference on Information Technology \& Society. Kuala Lumpur, Malaysia.

Ahmad, R., Hassan, H., \& Bahari, A. (2013). Persepsi Mahasiswa Terhadap Isu-Isu Perpaduan: Kajian ke Atas Pelajar-pelajar Rangkaian Universiti Teknikal Malaysia (MTUN). Jurnal Personalia Pelajar, 16, 15-24.

Davis, F. D. (1986). A Technology Acceptance Model for Empirically Testing New End-User Information Systems: Theory and Results. Sloan School of Management, Massachusetts Institute of Technology.

Fabil, N., \& Ismail, Z. (2018). Persekitaran Digital Islamik (IoDE) dalam Mereka bentuk Aplikasi Pengajaran Melalui Permainan Komputer. Jurnal Kepimpinan Pendidikan, 5(1), 78-91.

Galitz, W. O. (1997:13). The Essential Guide to User Interface Design: An Introduction to GUI Design Principles and Techniques. John Wiley \& Sons, Inc. New York, NY, USA.

Halim, H. A., \& Othman, Z. (2016). Strategi Promosi Melalui Laman Web: Kajian Kes di Sri Lovely Farm. In Symposium on Technology Management \& Logistics. Sintok. Universiti Utara Malaysia.

Hshim, Y. (2012). Penggunaan e-pembelajaran dalam pengajaran dan pembelajaran yang berkesan. Dalam Koncensyen Kebangsaan Pendidikan Guru (KKPG), 15-17.

Hussain, H., \& Shiratuddin, N. (2016). Kebolehpercayaan dan Korelasi Elemen Multimedia dan Antara Muka Tablet dalam Menilai Penceritaan Digital. Asia Pacific Journal of Educators and Education, 31, 27-45. https://doi.org/10.21315/apjee2016.31.3

Ishak, M. S. (2014). Pemodelan Penerimaan Maklumat Berkaitan Islam di Internet: Pengaplikasian Model Penerimaan Teknologi (TAM). Journal of Techno Social, 6(2), 49-61.

Jaafar, A., Abdullah, S., Latif, A. A., Paraidathathu, T., Ahmad, W. N. W., Daud, S., \& Salim, J. (2013) Penambahbaikan antara muka sistem penilaian pengajaran kursus (SPPK) UKM. AJTLHE: ASEAN Journal of Teaching and Learning in Higher Education, 5(2), 75-76. 
Junaini, S. N. (2014). Analisis Kebolehan Laman Sesawang Perpustakaan Universiti sebagai portal maklumat Sehenti. Jurnal PPM., 8, 17-25.

Najib, H. M., Bakar, N. R. A., \& Othman, N. (2017). E-Pembelajaran Dalam Kalangan Pelajar di Sebuah Institusi Pengajian Tinggi Selangor. Attarbawiy: Malaysian Online Journal of Education, 1(1), 74-82.

Nordin, H., \& Singh, D. (2016). Ulasan Elemen Reka Bentuk Antara Muka Bagi Meningkatkan Keterlibatan Pelajar Terhadap E-Pembelajaran di Institusi Pengajian. MyJICT - Malaysian Journal of Information and Communication Technology, l(2).

Rahayu, F. S., Setyohadi, D. B., \& Palyama, D. (2017). Analisis Penerimaan E-Leraning menggunakan Technology Acceptance Model (TAM) (Studi Kasus: Universitas Atma Jaya Yogyakarta). JUTEIEdisi, 1(2), 87-98. https://doi.org/10.21460/jutei.2017.12.20

Rahim, N. A., Affendi, N. R. N. M., \& Pawi, A. A. A. (2017). Dissemination of Values and Culture through the E-Folklore. The Turkish Online Journal of Educational Technology, 16(1), 32-36.

Rahim, N. A., Pawi, A. A. A., \& Affendi, N. R. N. M. (2018) Integration of Values and Culture in Malay Folklore Animation. Pertanika J. Soc. Sci. \& Humanities, 26(1), 359-374.

Rusdi, R., Noraidah Sahari @ Ashaari \& Noor, S. F. M. (2017). Garis Panduan Kebolehgunaan Antara Muka Laman Web Untuk Warga emas. Jurnal Teknology Maklumat dan Multimedia Asia-Pasifik, 6(2), 109-122.

Wibowo, A. (2008). Kajian Tentang Perilaku Pengguna Sistem Informasi Dengan Pendekatan Technology Acceptance Model (TAM). Proceeding Book of Konferensi Nasional Sistem Informasi 2008: Indenosia Modern Dalam Budaya Informasi, Yogyakarta 14-15 Januari.

Wook, T. S. M. T., Judi, H. M., Noraidah Sahari @ Ashaari, Mohamed, H., Noor, S. F. M., \& Rahim, N. (2016). Interaction Design Model in Virtual Museum Environment. Asia-Pasific Journal of Information Technology and Multimedia, 5(1), 71-81.

Yin, T. L., Ali, N. M., \& Noah, S. A. M. (2016). Interface Design Guidelines of Nutritional Information Application For The Elderly. Jurnal Teknologi Maklumat dan Multimedia Asia-Pasifik, 5(1), 1-13.

Zhang, J., Gu, P., Peng, Q., \& Hu, S. J. (2017).Open interface design for product personalization. CIRP Annals, 66(1), 173-176. https://doi.org/10.1016/j.cirp.2017.04.036

\section{Copyrights}

Copyright for this article is retained by the author(s), with first publication rights granted to the journal.

This is an open-access article distributed under the terms and conditions of the Creative Commons Attribution license (http://creativecommons.org/licenses/by/4.0/). 